Int. J. Electrochem. Sci., 16 (2021) Article ID: 210236

International Journal of

ELECTROCHEMICAL

SCIENCE

www.electrochemsci.org

\title{
Corrosion Behavior of Cast Iron in the Presence of Acidithiobacillus Ferrooxidans
}

\author{
Li Lin ${ }^{1,2,4}$, Cheng Liv $^{2,4}$, Lei Fu ${ }^{3}$, Ying Zeng ${ }^{1, *}$, Min Gong ${ }^{2,4, * *}$, Xue jun Cui ${ }^{2,4}$, Junchen Meng ${ }^{2,4}$, Xin jie \\ Huang $^{3}$ \\ ${ }^{1}$ College of Materials and Chemistry and Chemical Engineering, Chengdu University of Technology, \\ Chengdu 610059, China \\ ${ }^{2}$ Key Laboratory of Material Corrosion and Protection of Sichuan Province, Zigong 643000, China \\ ${ }^{3}$ School of Mechanical Engineering, Sichuan University of Science \& Engineering, Zigong 643000, \\ China \\ ${ }^{4}$ School of Material Science and Engineering, Sichuan University of Science \& Engineering, Zigong \\ 643000, China \\ *E-mail: zengy@cdut.edu.cn \\ ${ }^{* *}$ E-mail: gongmin@suse.edu.cn
}

doi: $10.20964 / 2021.02 .19$

Received: 1 October 2020 / Accepted: 28 November 2020 / Published: 31 December 2020

Ferrooxidans bacteria occur widely in acid mine drainage water. This work examined the corrosion behavior of cast iron in the presence of the acidophilic iron-oxidizing bacterium Acidithiobacillus ferrooxidans (T.f). Results showed this bacterium accelerated corrosion of cast iron by a factor of two compared with that of acidic ( $\mathrm{pH} 2$ ) water. This bacterium oxidizes ferrous ions to ferric ions as a source of energy and the produced ferric ions is quickly hydrolyzed to generate hydrogen ions, which partly offsets that consumed in the corrosion reaction. Besides, pitting was found on the cast iron surface in culture medium containing Acidithiobacillus ferrooxidans.

Keywords: Cast iron; MIC; Weight loss; morphology; EIS

\section{$\underline{\text { FULL TEXT }}$}

(C) 2021 The Authors. Published by ESG (www.electrochemsci.org). This article is an open access article distributed under the terms and conditions of the Creative Commons Attribution license (http://creativecommons.org/licenses/by/4.0/). 